\title{
Learner Use of Photo-Editing Software in Classes
}

\section{Marcus Grandon \\ University of Birmingham/University of Shizuoka}

\section{Reference Data:}

Grandon, M. (2020). Learner use of photo-editing software in classes. In P. Clements, A. Krause, \& R. Gentry (Eds.), Teacher efficacy, learner agency. Tokyo: JALT.

https://doi.org/10.37546/JALTPCP2019-60

In this classroom research project, 27 learners in three courses at one university use professionallevel, photo-editing software to create and remix images in language lessons. The overarching purpose of this study is to deepen understanding of what actually occurs in lessons through the use of materials. I delivered these lessons with a Content and Language Integrated Learning approach in which English was used for both the teaching and learning of not only lesson content but also language (Coyle, Hood, \& Marsh, 2010). Data include emails written by the learners to describe and evaluate their experiences with the software, digital artifacts created during the courses, and my research journal. Qualitative analysis is conducted in a grounded fashion using iterative coding (Saldaña, 2013) to identify emergent themes from a research perspective of materials use. Learners appear to demonstrate self-direction and creativity in highly personal ways throughout the lessons.

本授業調查研究ではある大学における3つのコースにおいて、27人の学習者が尃門家レベルの写真編集ソフトウェア を使用し、語学の授業内で画像の作成およびリミックスを行った。さの研究の包括的な目的は、学習者にてれら諸教村を用い を使用し、語学の授業内で画像の作成およびリミックスを行つた。この研究の包括的な目的は、学習者にてれら諸教材を用い ることにより授業中に起こることを深、理解させることである。本研究指導者は、授業内容だけでなく言語教育と学習の両方 に英語を使用するContent and Language Integrated Learning(内容言語統合型学習)によるアプローチを用いた (Coyle,

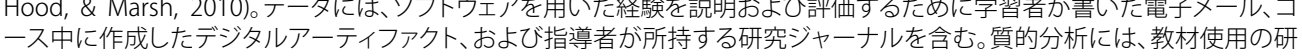

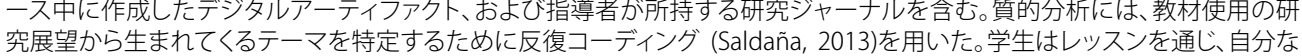
究展望からり生まれてくるテーマを方自己主性と創造性を示した。 $\mathrm{n}$ language courses today, modern technology is believed to provide motivating - and stimulating materials for language study. Yet little is understood about learner attitudes toward technology or ways in which the materials are used. After one student asked to learn how to create abstract images with a particular piece of sophisticated photo-editing software, I became interested in using the software in my English course and curious about conducting a classroom research project on use of these materials. Unfortunately, creating abstract images was not a part of the course syllabus, and the software required to make such images was unavailable on university computers at the time. I decided to email the educational-sales department at the American company that produced the software to enquire about securing full-use licenses. To my delight, the company generously agreed to donate the licenses under the following two conditions: (a) that I write up a report to inform the company of what unfolded in the lessons, and (b) that students share several examples of their work with the software for potential publication on the company blog. All participants agreed to these conditions.

Study set-up required minimal preparation because my aim was to explore use of the materials as natural classroom events, and I served dual roles as both teacher and researcher. I decided to deliver the lessons based on the pedagogic style of Content and Language Integrated Learning (CLIL). Due to the exploratory nature of classroom research, I crafted two questions to drive this research project:

1. How do learners perceive the use of the software in university courses?

2. What happens in classes when photo-editing software is used as lesson materials? Above all, the aim of this study focuses on the ways in which the participants use these materials for language lessons.

\section{Materials Use and CLIL Lessons}

Materials use or use of materials is a nascent line of inquiry in the field of TESOL. As a scope of research, materials use has its roots in over two decades of research in 
materials development and evaluation (e.g., McDonough, Shaw, \& Masuhara, 2013; McGrath, 2013; Tomlinson, 2011). Whereas the abundant and insightful literature on materials development and evaluation has concentrated on the production, content, and intent of materials themselves, research in materials use focuses on relationships between participants and the materials. A fundamental aim of materials use is to better understand what occurs when participants actually use lesson materials (Matsumoto, 2019). Guerrettaz et al. (2018) define materials use as "ways that participants in language learning environments actually employ and interact with materials" (p. 38). At the heart of materials use research lies inquiry surrounding the actions and processes in relation to participant interaction with materials.

Furthermore, because the primary sites for use of materials between teachers and students are language classrooms, materials use studies may often be considered as classroom research (Allwright \& Bailey, 1991). As such, materials-use research offers teachers, who may be best positioned to recognize and interpret what unfolds in classrooms, an avenue not only to reflect on practice but also to discuss classroom events in an evidence-based way.

Because materials use is such a new area of research, studies remain scarce. Existing studies have addressed diverse topics such as materials use in whole-group, teacherfronted interaction (Guerrettaz \& Johnston, 2013; Thoms, 2014), teacher adaptation of materials (Shawer, 2010; Marcos Miguel, 2015), the physical handling of documents by students (Jakonen, 2015), use of video-based materials by participants (Grandon, 2018), and materials use in writing classes (Matsumoto, 2019). In addition, Garton and Graves (2014) edited one of the first book-length treatments on materials use. Furthermore, Matsumoto (2019) suggests that research resembling the notion of materials use research may also include works done from perspectives such as classroom ethnographies (e.g., Duff, 1995) and those employing multimodal conversation analysis (e.g., Markee, 2011). Generally speaking, materials-use studies have shown materials to have a marked impact and heavy-handed influence on language development in both intended and unintended fashions.

Returning to the present study, as previously stated, I aim to better understand the use of materials in lessons delivered in a CLIL format. CLIL is a "dual focused educational approach in which an additional language is used for the learning and teaching of both content and language" (Coyle, Hood and Marsh, 2010, p. 1). The approach balances the additional language with content learning in a variety of possible ways, and instructional focus leans more heavily on the content in some contexts, while in other contexts the language training is given priority (Wolff, 2011). As such, a CLIL approach offers flexibility to the degree with which lessons focus on the content and the language. I taught the use of the photo-editing software in English to three groups of native Japanese speakers at one university in Japan where the course content, i.e., the software and its use, was foregrounded over the language being taught in the classroom activities.

\section{Classroom Activities}

In the current study, learners in three elective courses used the photo-editing software to complete classroom activities. These courses included two Business English courses and one Internet English course, and I taught these software-based lessons as supplemental materials in each course. In all, I delivered 11 hours of instruction to each group in the software-based lessons, which represents $24 \%$ of the total course time. Learners were also asked to demonstrate proficiency in image editing during a timed section of their final exams.

I structured the image-editing lessons in an iterative way so that the more advanced features of the software could be introduced slowly over successive weeks and used tutorial videos from the company website as materials. While learners watched, I paused the videos to explain and clarify points in the English voice-overs. Then, I demonstrated and explained the techniques further before asking the students to experiment with the software. The main thrust of these lessons consisted of studying ways to use the vast number of effects in the software and apply these tools to images. In addition, 1 introduced the learners to concepts related to image production such as image-design techniques, art history, and international copyright law.

Lessons included seven main activities: (a) experimenting with basic effects on day one, (b) creating several versions of a self-portrait, (c) creating remixes of digital images from a well-known museum, (d) making business logos for a faux advertising campaign, (e) using images to create entirely new images/multi-photo layering, (f) using students' own photos, and (g) creating abstract images. The basic tools of the software are intuitive and contain thousands of preset effects. Novices are able to create compelling images within minutes of first opening the software. At the same time, there is a high-level of sophistication to the more advanced tools that require training. Figure 1 is an example of a selfie created by a student using a combination of effects. 


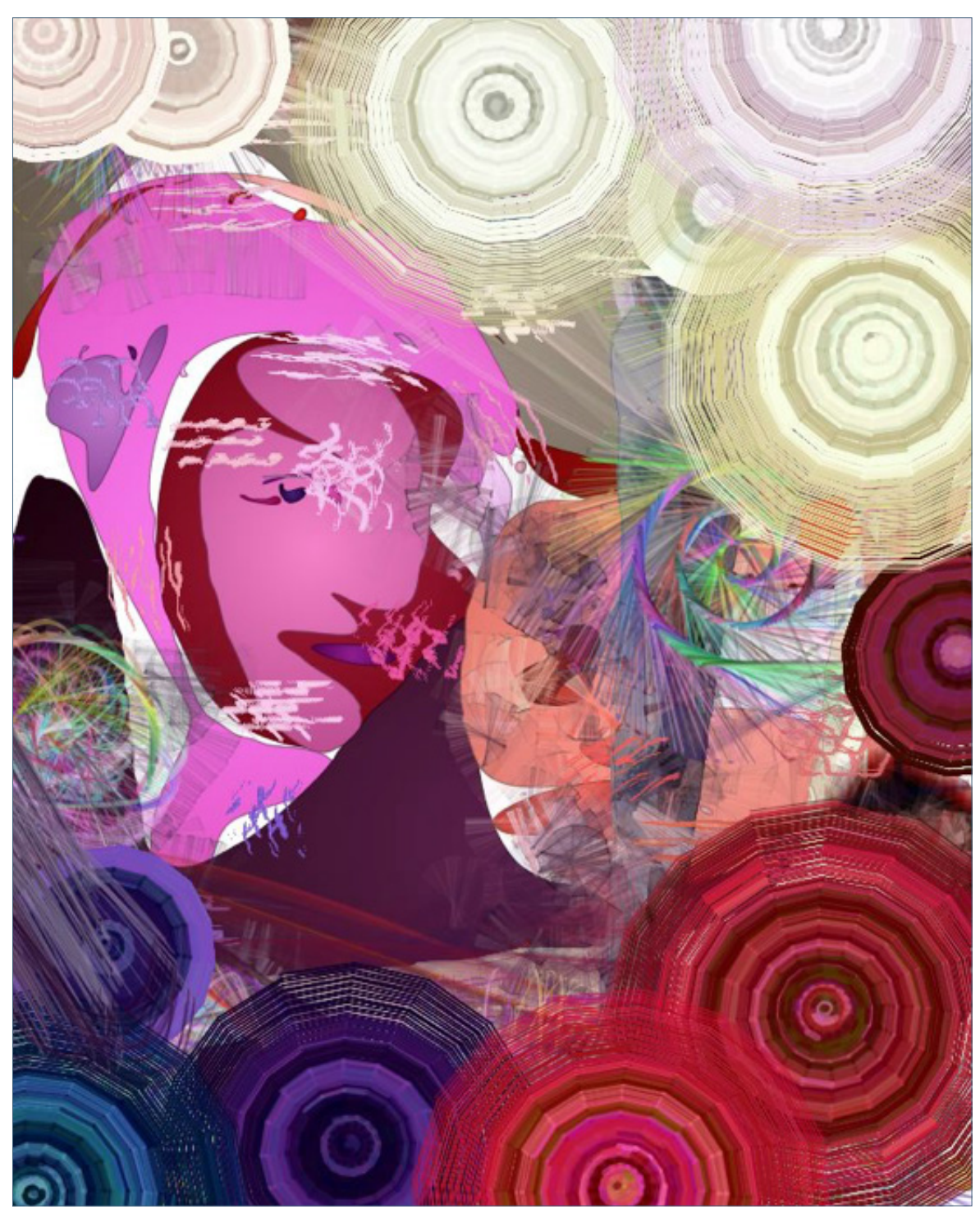

Figure 1. Example of a student using a combination of effects on a selfie.
With the voluminous remixing of digital assets today (TED, 2010), art museums and other organizations with photo archives have begun to rethink their positions regarding copyrights. Following this trend, the Metropolitan Museum of Art in New York City (MET) has opened a digital archive of 400,000 images freely available for scholarly purposes. These open-access images even include photos of works by famous artists such as Gustav Klimt, John La Farge, and Joseph Turner. Students were directed to the MET website for digital content to remix in the software. Figure 2 displays an example of an open-access, MET image by La Farge (1887) and the result of student editing. With such editing and remixing, the learners may be considered to be collaborating with famous artists. Searching the open-access archives, then editing and remixing these images became a focus of the classroom activities.
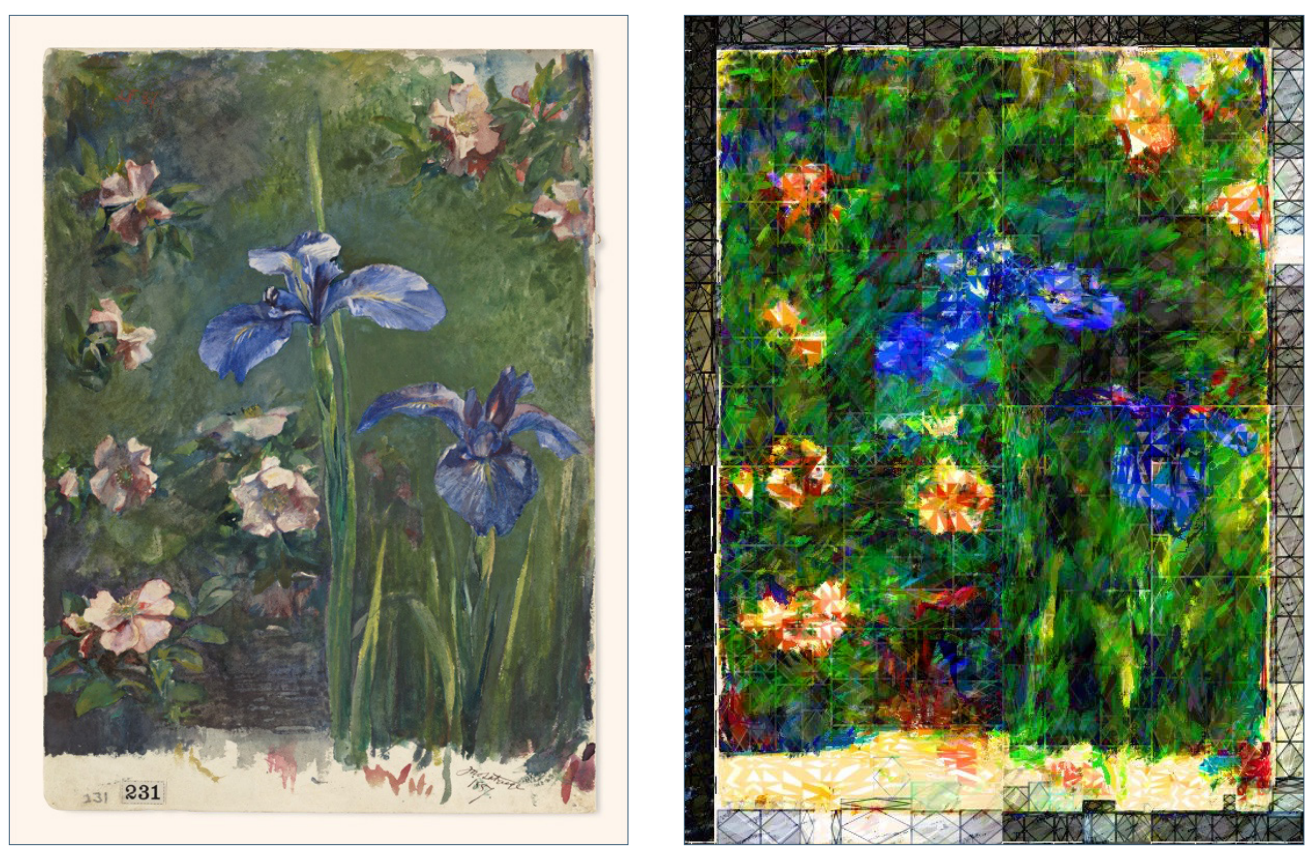

Figure 2. The original image (left) is courtesy of The Metropolitan Museum of Art. Gift of Priscilla A. B. Henderson, in memory of her grandfather, Russell Sturgis, a founder of The Metropolitan Museum of Art, 1950. Used by permission (www.metmuseum.org). 


\section{Research Methods}

I secured consent from all participants for this project. Data consist of self-reflective emails where the learners wrote about what they had learned using the software in the classes. Learners submitted the emails at the end of the semester, and all student names below are pseudonyms. I also kept a research journal to document classroom observations as is often done in qualitative research. Observation notes serve as empirical data when kept systematically (Dörnyei, 2007). Lastly, digital artifacts created by the learners were collected. Such a diverse data set allows for layers of depth to analysis because self-reports and empirical observations can be combined.

\section{Data Analysis and Results}

In total, 27 reflective emails were collected, printed, tagged with unique ID numbers, and analyzed in a grounded fashion (Corbin \& Strauss, 2008). I first read the emails without any coding to formulate overall impressions and then applied open coding, which are descriptions of segments of raw data, to 211 unique clauses to delineate broad concepts. Finally, I coded these email data in an iterative, two-cycle process by first using structural codes to identify paradigms and then coded again with pattern coding to develop categories (Saldaña, 2013). Rather than develop codes from my journal observations, I generated them from the student emails so that student voices drove the development of the categories in order to add credibility to analysis. Based on these coded responses, seven categories emerged as Table 1 shows.

Table 1. Emergent Categories in Student Emails

\begin{tabular}{lcc}
\hline Category & Number & Percentage \\
\hline Positive attributes & 48 & $22 \%$ \\
Personal Use & 42 & $20 \%$ \\
Creativity & 36 & $17 \%$ \\
Opinions on Software & 33 & $16 \%$ \\
Technical Skills & 26 & $12 \%$ \\
Expanded Worldview & 14 & $7 \%$ \\
Developing English & 12 & $6 \%$ \\
Total responses coded & 211 & $100 \%$ \\
\hline
\end{tabular}

Next, I analyzed my teacher research journal through the technique of constant comparison, which is when segments of data are compared to each other to learn about similarities and differences (Merriam, 2009). In subsequent passes through my journal entries, I matched passages to the coding categories found in the student emails as Table 2 shows. Furthermore, I looked for ways that the images produced in class compared to the categories. I highlight five of these categories as related to my research questions on materials use below.

Table 2. Example Extracts for Each Category

\begin{tabular}{|c|c|c|}
\hline Category & Email extract & Journal extract \\
\hline Positive attributes & $\begin{array}{l}\text { "It was a good experience } \\
\text { for me..." }\end{array}$ & $\begin{array}{l}\text { "The software generated a great } \\
\text { deal of excitement in the class." }\end{array}$ \\
\hline Personal use & $\begin{array}{l}\text { "I printed a processed a } \\
\text { photo and displayed it in } \\
\text { my room." }\end{array}$ & $\begin{array}{l}\text { "One [student] uploaded his work } \\
\text { to FLICKR immediately without me } \\
\text { even telling him to do it." }\end{array}$ \\
\hline Creativity & $\begin{array}{l}\text { "I like using [the software] } \\
\text { because I can feel like I } \\
\text { became a famous artist!!" }\end{array}$ & $\begin{array}{l}\text { "I noticed one student really started } \\
\text { to develop a style of his own and } \\
\text { apply it to multiple images." }\end{array}$ \\
\hline $\begin{array}{l}\text { Opinions on } \\
\text { software }\end{array}$ & $\begin{array}{l}\text { "...this is a very high } \\
\text { quality application and we } \\
\text { can choose many types of } \\
\text { effects." }\end{array}$ & $\begin{array}{l}\text { "Others mentioned that they really } \\
\text { looked forward to the lesson on } \\
\text { Thursday." }\end{array}$ \\
\hline Technical skills & $\begin{array}{l}\text { "I was especially excited } \\
\text { about the layers." }\end{array}$ & $\begin{array}{l}\text { "One student had no idea he could } \\
\text { drop and drag an image from a } \\
\text { website to the desktop." }\end{array}$ \\
\hline $\begin{array}{l}\text { Expanded } \\
\text { worldview }\end{array}$ & $\begin{array}{l}\text { "...people who can't draw } \\
\text { good pictures (like me!) are } \\
\text { also able to try drawing." }\end{array}$ & $\begin{array}{l}\text { "Browsing the catalog it was hoped } \\
\text { would expose the students to some } \\
\text { of the } 400,000 \text { images offered } \\
\text { online from the museum's catalog } \\
\text { to increase appreciation of art." }\end{array}$ \\
\hline $\begin{array}{l}\text { Developing } \\
\text { English }\end{array}$ & $\begin{array}{l}\text { "I worked hard on studying } \\
\text { English to use [the } \\
\text { software]." }\end{array}$ & $\begin{array}{l}\text { "... a real need arose for language } \\
\text { and meaningful communication in } \\
\text { English..." }\end{array}$ \\
\hline
\end{tabular}




\section{Positive Attributes}

As I anticipated, these student responses about the software and its use were overwhelmingly positive. With the software only available to them during class time, students often stayed at their computers after the class had finished and on multiple occasions had to be asked to step away from the machines due to time constraints because the next group was eagerly waiting to get into the classroom. In addition, comments about emotions were included in this category. In their emails, students repeatedly used emotional terms such as "exciting", "fun" and "enjoyment" to characterize their experience. Eliciting of positive emotions during educational experiences has been shown to aid in learner motivation and language learning (e.g., Méndez López, 2011). By reporting with cheerful language, student perceptions of using these materials appear to be associated with a positive classroom experience.

\section{Personal Use}

Students seemed to operate with autonomy by taking an apparent pride and ownership over their edited images. Personal use of the images occurred when students acted on their own to do something personal with their images that was not a part of the required classroom instruction. Two types of personal use make up this category: real personal use and future personal use. In real personal use, students either reported that they had done something with their images unrelated to classroom instruction or were observed doing so in class. In such actions, images created in class were: (a) printed and displayed in student apartments, (b) used on Instagram, (c) tweeted to friends, (d) shown to parents, (e) uploaded to Flickr, (f) emailed to friends, and (g) used for wallpaper on phones or computers.

Future personal use occurred when students reported plans they had for their images. These planned uses consisted of similar notions to real personal use, while also containing more lofty aspirations such as printing T-shirts, making greeting cards, or using the software as teaching materials upon securing a teaching position after graduation. One long-held belief in language teaching is that if a learner can recognize ways in which a foreign language has practical relevance then a deeper understanding of the communicative nature of language develops (Widdowson, 1978). Because learners deemed these images worthy of being shared on a personal level, the category of personal use indicates that learners demonstrate a personal significance and practical relevance to the content of their classroom work.

\section{Creativity}

Learners appeared to use the software in creative ways by applying multiple effects to images that resulted in original pieces of art. Effects were used to inject an artistic style into their images, and the students appeared engaged while creating their original works. In class, learners expressed surprise and delight with the creative capabilities of the software and reported attempts to imbue images with high-held values for communicative purposes, which may suggest an awareness of multimodal communication. For example, Figure 3 displays an image by a student, Kenji, where he used color and design techniques to create a visual message. Kenji seems to perceive the use of the software as a means to express himself in more than just words. The upper-left corner of the image in Figure 3 appears bright with its yellows and oranges. If one views this image beginning in the upper-left and lets the eyes travel diagonally downwards to the lower, right-hand corner, there is a gradual decent into the darkness of the blues. In his owns words, Kenji explains what he was attempting to achieve, "I tried to explain my mind that contains a kind mind and something of a violent mind." Through use of color and design in imagery, Kenji endeavors to represent two aspects of his mental state that perhaps juxtapose a fundamental kindness with adolescent angst.

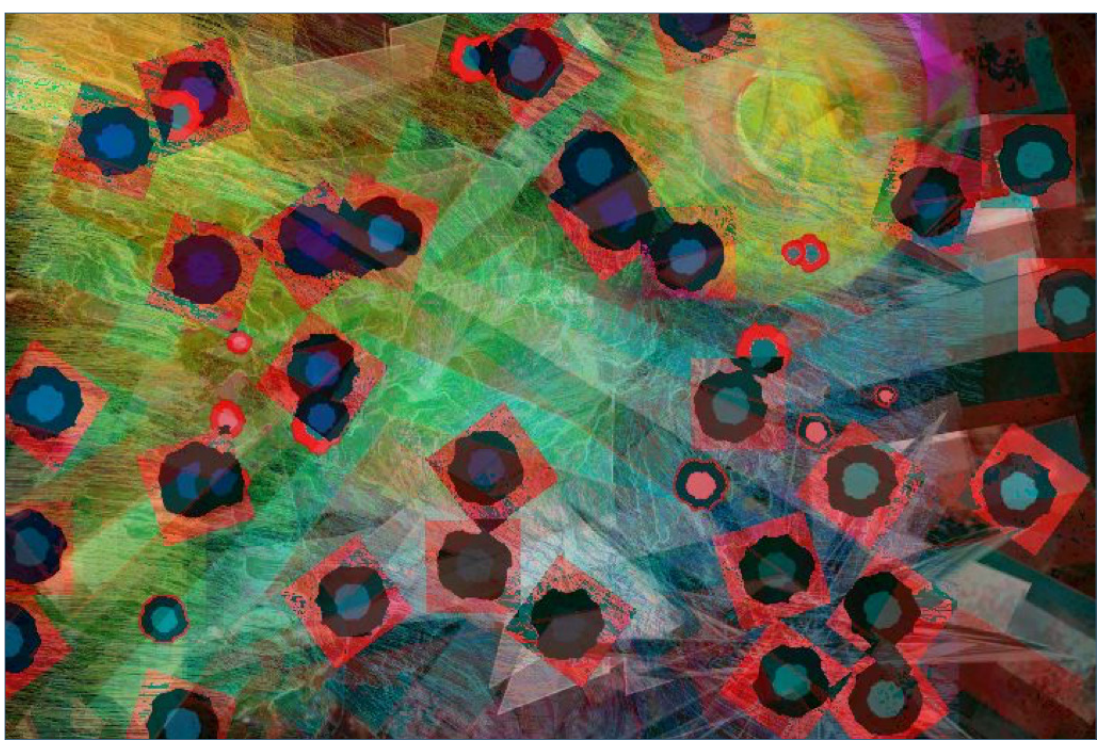

Figure 3. Kenji's abstract image. 
During other activities, learners appeared to take control of their work by moving assignments in a direction of their own choosing. For example, in adapting the activity at hand, which was to download one image and add particular effects to it, Yuka created multiple versions of her own work based on a single MET image. In doing so, Yuka appears to adapt in a creative way. After watching her adapt the activity, I thought it such a good idea that I started asking other students to do a similar thing. Furthermore, the remixing of images from famous artists appear to give rise to a sense of accomplishment and collaboration.

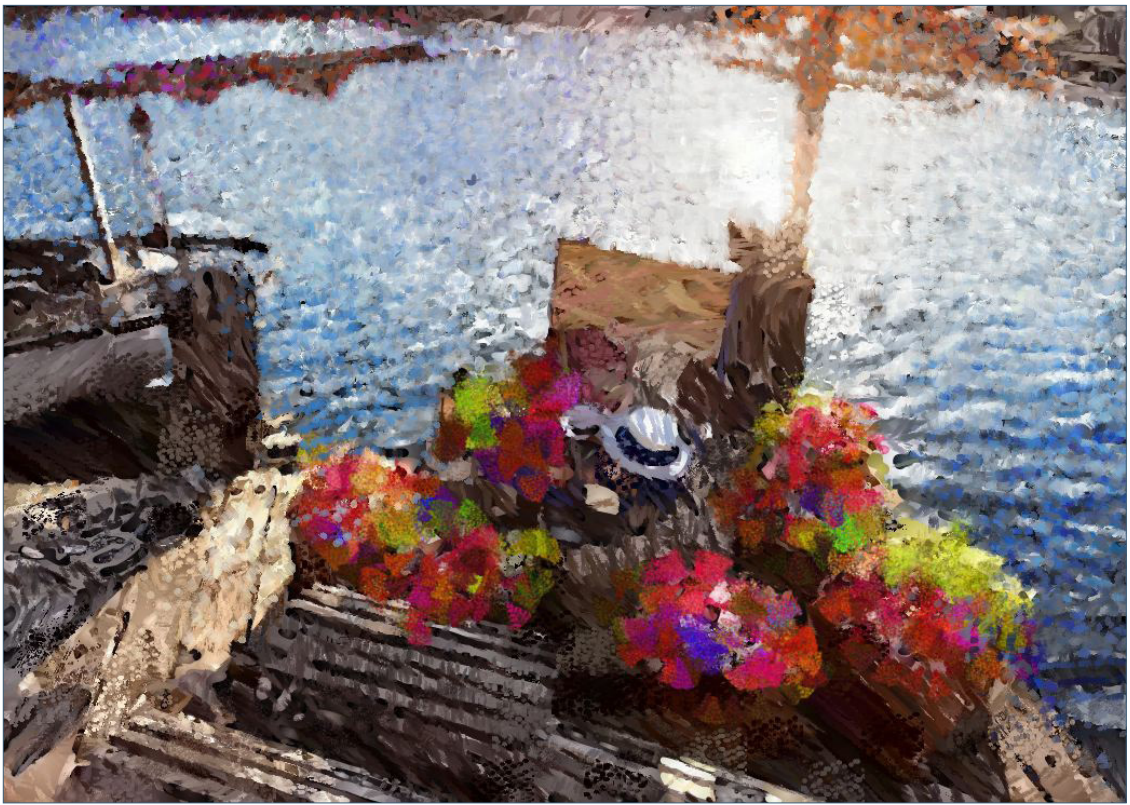

Figure 4. Miho's edited image taken with a cell phone.

More than once, I mistook edited images that students had taken with their phones for remixes of those that had been downloaded from the MET. For example, when one student, Miho, turned in the image depicted in Figure 4 for her assignment, I asked her why she had failed to cite the appropriate copyright information for the original image as requested by the MET. In fact, Miho had taken the original image with her phone, so she held the copyright. As such, an episode of meaningful communication arose in relation to creativity and the materials: the student was in a position to defend her work to a person of authority. Most likely, Miho summoned some degree of both courage and confidence when she stood her ground to point out my mistake to my face. Somewhat embarrassed, I humbly apologized. Through the creative nature of classroom activities, students may not only come to a better understanding of ownership over work but also create works of artistic merit. Overall, the creativity and playful characteristics exhibited in class and reported by the students appear to show a creative use of the materials. As such, learners seem to put creativity to use when such software is used as lesson content and perceive a flexibility in the activity instructions.

\section{Technical Skills}

Use of the software as materials also seemed to address technical skills. Using the tools in the software appears to have led students to a greater understanding of the technical aspects of processing images and interest was piqued by advanced techniques such as remixing through photo layering (Table 2). Likewise, as a part of materials use, students seemed to develop some generic skills of digital literacy. As noted in my journal, some participants appeared unfamiliar with even basic computer skills such as installing applications from a USB drive, copying and downloading photos, saving versions of images, using keyboard short-cuts, or saving images in different file formats. Students asked questions like, "How do I download a picture [from the web]?" and, "How can I change the size of this picture?" Because students wanted to do different things with their images in the digital world, deficiencies in basic computer skills surfaced and solutions could be presented. Thus, use of image editing software and remixing appears to impact the noticing of gaps in computer-literacy skills.

\section{Developing English}

Although students clearly recognized the setting as a language course, most of their responses about their learning experiences focused on using the software rather than on developing language. For example, while Kenji was not asked to describe the meaning of his abstract photo (Figure 3) as part of the activity, he seems to have felt compelled to write about its meaning when turning in his assignment. As such, use of the software may have inspired meaningful communication in English. Students did refer to the learning of vocabulary as related to technology and software. Even in the saving and exporting of their digital files, vocabulary was studied as learners looked up words to make English names for images. Learners seemed to reflect more on the studying of

\section{FRONT PAGE}


the course content over language, which aligns with the way in which the content was foregrounded over language skills by the teacher.

On the other hand, many entries in my research journal related to instances of language instruction in terms of materials use and what unfolded in these lessons. Chances for meaningful interaction were plentiful within teacher/student interaction around the computers during the activities involving the processing of images as explained in the above section on technical skills. In addition, the learners regularly asked questions about how to do specific tasks with the software and initiated this interaction in English. The language choice was encouraging because it would have been easier for students to ask these questions in their mother tongue. These questions seemed to be asked with purpose and urgency. Such interaction often resulted in meaningful English exchanges tailored to individual students, which provided space for one-on-one attention. This triadic relationship of student-teacher-software appears to represent a context where language development is part of the action and provides what van Lier (2002) calls "an ambient array of opportunities for meaning making" (p. 147). By viewing the participant actions surrounding the use of materials, this relationship comes clear.

\section{Discussion}

I wish to highlight three main contributions of this small-scale study. First, findings appear to support the viability of using software as content for CLIL-based teaching, particularly when creative projects are involved in activities. Students' desire to learn software functionality may help lead to not only meaningful communication around computers but also imaginative production of work. The emergence of these two lesson components suggests support for the dual-focused notions of attention to language and attention to content in CLIL theory. Moreover, use of learner-generated materials themselves may aid in setting up conditions for meaningful communication such as when Kenji explained the meaning of his abstract image and when Miho informed me about the origins of her photo.

Second, the decentralized nature of creative activities seems to help generate conditions that may facilitate opportunities for self-direction. Learners appear to have worked in creative and spontaneous manners, and they often controlled the direction of the editing/remixing in multiple ways such as selecting images to remix from online archives and choosing which effects to apply to images. In doing so, the learners appear to act with degrees of volition, initiative, and autonomy. At the same time, this seemingly autonomous control over the direction of the activities may be one reason that learners perceived the lessons to be such a positive learning climate, which indicates a potential benefit of self-directed activities. Both Robinson (TED, 2013) and Marsh (2012) identify creativity as a key component of educational reform, and students seem to welcome activities that request creativity by responding with curiosity and autonomy.

Third, and perhaps most importantly, these findings draw attention to an underexplored aspect of materials use by revealing ways in which a personal use of materials may be a consequence of classroom activities. Whereas research on personal perspectives related to language learners tends to focus on a standpoint of personal learner beliefs (e.g., Gao, 2010; Mercer, 2011), actions in the present study indicate that use of materials may have a practical component, i.e., learners may bring the results of classroom work into their personal lives. In doing so, learners appear compelled to share what they have done while seemingly involved with a creative process during these lessons, which indicates a sense of pride in and ownership over the work. Language teachers and researchers have argued for educational changes to include activities that move beyond the confines of the classroom (Marsh, 2012), and learners in this study both demonstrate and report personal uses of their images that extend beyond the boundaries of the classroom walls and instructional requirements for the activities. This personal use of the materials suggests that both the skills studied and the images produced may be perceived as relevant and important to the participants outside of the classroom, thereby demonstrating ways with which language lessons can have meaning for students' personal lives. Furthermore, this personal use shows how CLIL-based activities may support a movement of pedagogic experiences from the classroom to society at large.

In this study, I explored the use of photo-editing software in relation to materials use. Through emergent categories of positive attributes, personal use, creativity, opinions on software, technical skills, expanded worldview, and developing English; I was able to better understand not only learner perceptions of software use but also what actually happens when such software is used as lesson materials. Accordingly, the implications of this study for language teaching indicate support for classroom activities that involve creativity such as media production, poster design and presentation, spontaneous speaking activities, and free writing.

\section{Acknowledgements}

Many thanks to the software company for generously donating the full-use licenses ( $¥ 1,300,000$ value). I have no professional affiliation with the company and have paid the full price for my personal copy of the software. 


\section{Bio Data}

Marcus Grandon holds a PhD in Applied Linguistics from Aston University. His research focuses on the use of materials for language lessons in Japanese university classrooms. <marcusgrandon@mac.com> or https://museinternational.wordpress.com/

\section{References}

Allwright, D., \& Bailey, K.M. (1991). Focus on the language classroom. Cambridge: Cambridge University Press.

Corbin, J., \& Strauss, A. (2008). Basics of qualitative research: Techniques and procedures for developing grounded theory (3rd ed.). Thousand Oaks, CA: Sage Publications.

Coyle, D., Hood, P., and Marsh, D. (2010). CLIL: Content and language integrated learning. Cambridge: Cambridge University Press.

Dörnyei, Z. (2007). Research methods in applied linguistics. New York: Oxford University Press.

Duff, P. (1995). An ethnography of communication in immersion classrooms in Hungary. TESOL Quarterly, 29, 505-537. https://doi.org/10.2307/3588073

Gao, X. (2010). Strategic language learning: The roles of agency and context. Bristol: Multilingual Matters.

Grandon, M. (2018). Exploring the use of video-based materials in the Japanese university English language classroom. Unpublished doctoral thesis. Aston University, Birmingham, UK.

Guerrettaz, A. M., Grandon, M., Lee, S., Mathieu, C., Berwick, A., Murray, A., \& Pourhaji, M. (2018). Materials use and development: Synergetic processes and research prospects. Folio, 18, 37-44.

Guerrettaz, A. M., \& Johnston, B. (2013). Materials in the classroom ecology. Modern Language Journal, 97, 779-796. https://doi.org/10.1111/j.1540-4781.2013.12027.x

Jakonen, T. (2015). Handling knowledge: Using class- room materials to construct and interpret information requests. Journal of Pragmatics, 89, 100-112. https://doi.org/10.1016/j. pragma.2015.10.001

La Farge, J. (1887). Wild roses and irises (Gouache and watercolor on white wove paper). New York: The Metropolitan Museum of Art. www.metmuseum.org

Marcos Miguel, N. (2015). Textbook consumption in the classroom: Analyzing a classroom corpus. Procedia-Social and Behavioral Sciences, 198, 309-319.

Markee, N. (2011). Doing, and justifying doing, avoidance. Journal of Pragmatics, 43, 602-615. https://doi.org/10.1016/j.pragma.2010.09.012

Marsh, D. (2012). Content and integrated language learning (CLIL): A development trajectory. Unpublished doctoral thesis. University of Córdoba, Córdoba, Spain.
Matsumoto, Y. (2019). Material moments: Teacher and student use of materials in multilingual writing classroom interactions. The Modern Language Journal, 103(1), 179-204. https://doi. org/10.1111/modl.12547

McDonough, J., Shaw, C., \& Masuhara, H. (2013). Materials and methods in EFL (3rd ed.). Chichester, UK: John Wiley \& Sons.

McGrath, I. (2013). Teaching materials and the roles of ELF/ESL teachers: Practice and theory. London: Bloomsbury.

Méndez López, M. G. (2011). The motivational properties of emotions in foreign language learning. Colombian Applied Linguistics Journal, 13(2), 43-58. https://doi. org/10.14483/22487085.3764

Mercer, S. (2011). Understanding learner agency as a complex dynamic system. System, 39(4), 427436. https://doi.org/10.1016/j.system.2011.08.001

Merriam, S.B. (2009). Qualitative research: A guide to design and implementation. San Francisco, CA: Jossey-Bass.

Saldaña, J. (2013). The coding manual for qualitative researchers. London: Sage Publications Ltd.

Shawer, S. F. (2010). Classroom-level curriculum development: EFL teachers as curriculumdevelopers, curriculum-makers and curriculum-transmitters. Teaching and Teacher Education, 26(2), 173-184. https://doi.org/10.1016/j.tate.2009.03.015

TED. (2010, June 1) Lawrence Lessig: Re-examining the remix [Video file] retrieved from https:// www.youtube.com/watch?v=xyf_0SMAsFA\&ab_channel=TED

TED. (2013, May 13) Ken Robinson: How to escape education's Death Valley [Video file] retrieved from https://www.youtube.com/watch?v=wX78iKhInsc\#t=42

Thoms, J. J. (2014). An ecological view of whole-class discussions in a second language literature classroom: Teacher reformulation as affordances for learning. Modern Language Journal, 98 724-741. https://doi.org/10.1111/modl.12119

Tomlinson, B. (Ed.). (2011). Materials development in language teaching (2nd ed.). Cambridge: Cambridge University Press.

van Lier, L. (2002). An ecological-semiotic perspective on language and linguistics. In C. Kramsch (Ed.), Language acquisition and language socialization: Ecological perspectives (pp. 140-164). London: Continuum.

Wolff, D. (2011). CLIL and learner autonomy: Relating two educational concepts. Education et Sociétés Plurilingues, 30, 69-80. 